\title{
DUSP5 Gene
}

National Cancer Institute

\section{Source}

National Cancer Institute. DUSP5 Gene. NCI Thesaurus. Code C111862.

This gene is involved in the dephosphorylation of ERK family proteins. 